\title{
The COVID-19 epidemic in Poland and its influence on the quality of life of university students (young adults) in the context of restricted access to public spaces
}

\author{
Agnieszka Szczepańska ${ }^{1}$ (D) Katarzyna Pietrzyka ${ }^{1}$
}

Received: 17 July 2020 / Accepted: 3 December 2020 / Published online: 7 January 2021

(C) The Author(s), under exclusive licence to Springer-Verlag GmbH, DE part of Springer Nature 2021

\begin{abstract}
Aim The aim of this study was to determine the impact of social distancing, self-isolation and limited access to public spaces during the COVID-19 pandemic on the quality of life and psychological well-being of young people.

Subject and methods The coronavirus disease 2019 (COVID-19) pandemic caused by the SARS-CoV-2 virus posed a new global challenge in 2020. The new coronavirus emerged locally, but it rapidly spread to all continents and also reached Poland. On 24 March, the Polish Ministry of Health enforced self-isolation measures to contain the transmission of the disease. The new regulations imposed restrictions on civic freedoms, including access to public spaces. These measures significantly affected the daily lives of Polish citizens. Public spaces play a fundamental role in catering to the citizens' basic needs. Access to public spaces is directly correlated with the quality of life, human relations and spontaneous interactions. Young people are highly socially active, and they are frequent users of public spaces. University students (young adults) who transitioned to online learning on 12 March were surveyed remotely with the Microsoft Forms online tool. The questionnaire contained several questions to elicit demographic information about the respondents, as well as 25 closed-ended questions relating to university students' quality of life and access to public spaces during the epidemic. The survey was carried out during the first Polish lockdown in April 2020. The study group was composed of 132 respondents who were university students aged 19-26.

Results The results revealed a strong correlation between the severity of lockdown measures during the epidemic and the students' activity levels in public spaces, a considerable deterioration in their physical and psychological well-being, and the overall quality of life.

Conclusion The respondents were significantly affected by the absence of direct social interactions which, in their opinion, can be only partially compensated for by remote contact.
\end{abstract}

Keywords COVID-19 epidemic $\cdot$ Public space $\cdot$ Social and physical activity $\cdot$ Psychological well-being

\section{Introduction}

Young people are highly socially active, and they are among the most frequent users of public spaces. Public spaces enable community members to enter into social interactions, establish

Agnieszka Szczepańska

aszczep@uwm.edu.pl

Katarzyna Pietrzyka

katarzyna.pietrzyk@uwm.edu.pl

1 Department of Socio-Economic Geography, University of Warmia and Mazury in Olsztyn, ul. Prawocheńskiego 15,

10-724 Olsztyn, Poland new social relations, participate in sports and recreational activities, attend artistic and cultural events, and enjoy nature (Amin 2008; Aydin and Ter 2008; Carr et al.1992; Crane 2000; Derek 2014; Hampton et al. 2015; Hanan 2013; Huynh et al. 2013; Mitchell 1995; Shaftoe 2012; Tonnelat 2010; Wood et al. 2017).

Open spaces promote physical and psychological regeneration; they help residents feel calm and relaxed, and improve mood and relieve stress. Public spaces contribute to the psychological and physical well-being of community members (Braubach et al. 2017; Francis et al. 2012; Degórska 2004; Santi and Leporelli 2019; Sikorska 2010). The social distancing measures enforced during the COVID-19 pandemic restricted access to public spaces and significantly limited outdoor social and physical activities (Honey-Rosés et al. 2020; 
Jasiński 2020; Lesser and Nienhuis 2020; Nobajas et al. 2020). This new and unprecedented crisis has affected public moods and behavior. Changes in daily routines, social distancing, partial or complete isolation and the existing health risks lead to emotional distress (Canet-Juric et al. 2020; Ćosić et al. 2020; Duszyński et al. 2020; Heitzman 2020).

The coronavirus disease 2019 (COVID-19) is caused by the SARS-CoV-2 virus. In Poland, the first confirmed case was recorded on 4 March 2020. A state of epidemiological threat was introduced between 14 and 20 March, and a state of epidemic emergency was declared on 20 March pursuant to a Regulation of the Minister of Health (2020). Polish universities began suspending classes on 10 March, and all universities closed down on 12 March. Public gatherings were banned, movement of persons and access to public spaces were restricted, and direct social interactions were limited by the Regulation of the Minister of Health of 24 March 2020. Strict restrictions which nearly completely banned the use of public spaces remained in force until 20 April.

The study involved a survey of university students (young adults) who were asked to describe the effect of the state of emergency declared in Poland over the COVID-19 epidemic on their perceptions and use of public spaces. The survey was conducted during the national quarantine period between 6 and 21 April 2020. The aim of this study was to determine the extent to which limited access to public spaces has affected the physical and psychological well-being of young people, to identify daily activities that have been most severely compromised during the pandemic, and to determine whether remote communication can adequately compensate for the lost social interactions.

\section{Psychological well-being and the social and physical activity of young people}

The prevalence of mood disorders among young people has risen in recent years. Mood disorders are increasingly diagnosed in university students. A study conducted by Białkowska et al. (2014) on 298 university students revealed that mood disorders affect every eighth young adult, and $12.4 \%$ of the surveyed population had suffered from a depressive episode. Women are more susceptible to depression than men. Similar results were reported by Jaworska et al. (2014) who surveyed 153 university students and found that $19 \%$ of the respondents were manifesting mood problems (serious symptoms were diagnosed in $8 \%$ of the studied population). The majority of the affected respondents were women. These findings have been confirmed by other studies (Adamiak et al. 2004; Eckersley et al. 2005; Gruszczyński et al. 2008; Marek et al. 2005; Wilczewska 2013), which indicates that mood disorders pose a serious problem in academic communities.
Depressive episodes are often linked with financial problems, sense of loneliness, social isolation and lack of physical activity (Białkowska et al. 2014; Cieślik et al. 2015; Jaworska et al. 2014; Szczepańska et al. 2008). These factors were exacerbated by lockdown rules which deprived many students of jobs and a source of income (many students work while at university), led to the closure of fitness clubs, swimming pools, gyms and public recreational areas (parks, forests), and introduced mandatory social distancing.

According to Marek et al. (2005), university students prefer "positive" solutions to dealing with negative emotions, which include social interactions and sports - activities that generally require access to public spaces. Human interactions and sharing emotional experiences with others are essential for social functioning (Białkowska et al. 2014; Lopes et al. 2005; Moturu et al. 2011; Schwerdtfeger and Friedrich-Mai 2009). Sports and recreation play a similarly important role, and mood disorders were found to be strongly correlated with low levels of physical activity. Physical exercise contributes to an improvement in the quality of life (Biddle et al. 2003; Bray and Born 2004; Brooks and Magnusson 2007; Caldwell et al. 2009; Legey et al. 2017; Lakomski et al. 2017; Taras 2005 Uramowska-Zyto et al. 2004).

Prolonged isolation can lead to a significant decline in mood (Palinkas et al. 2004). During the pandemic, face-to-face interactions were replaced by online social networking and telephone communication. Virtual communication has evolved with the emergence of the Internet, messaging services and social networks (Anderson 2001; Długosz 2020; Jones 2008; Koszel et al. 2015; Krajewska-Kułak et al. 2010; Lis 2010), and these tools are particularly popular among individuals suffering from social anxiety (Caplan 2003; Çuhadar 2012). Excessive Internet use is sometimes viewed as an asocial behavior that is linked with mood disorders, but during the COVID-19 crisis, the Internet significantly helped people socialize (Banjanin et al. 2015; Chen and Peng 2008; Marcinkowski et al. 2010). University students relied on online tools to communicate with their peers, build and maintain relationships with friends, and remain socially connected (Cain 2008; Martínez-Alemán and Wartman 2008; Park 2010; Swist et al. 2015; Wyn et al. 2005). The virtual environment, online public space and online communities completely replaced physical public spaces during the pandemic (Hampton et al. 2010; Király et al. 2020; Li 2010; Prakash et al. 2020).

Długosz (2020) reported a visible decline in the psychosomatic well-being of university students during the COVID-19 lockdown. Social distancing leads to anxiety and tension. The sudden change in daily routines and uncertainty about the future exacerbate stress. The pandemic exerted a highly negative influence on social moods, including in the academic community (Armitage and Nellums 2020; Cao et al. 2020; Długosz 2020; Fiorillo and Gorwood 2020; Ho et al. 2020; $\mathrm{Li}$ et al. 2020; Lima et al. 2020; Montemurro 2020; Torales et al. 2020; Wang et al. 2020). 


\section{Materials and methods}

The study involved a diagnostic survey with a questionnaire. This research method was used to collect quantitative and qualitative data. The questionnaire was composed of 25 survey questions and four demographic questions (age, sex, type of university program, year of study). Survey questions addressed the type and frequency of daily activities undertaken by the respondents in public spaces, the psychological impact of social distancing, and the use of modern tools for social communication. Concepts such as the state of epidemic emergency, public spaces, open spaces and closed spaces were defined in the introduction to the questionnaire.

The questionnaire comprised closed-ended questions, including yes/no questions, single-choice questions (only one response can be selected from the list) and multiple-choice questions (more than one response can be selected from the list).

The respondents were targeted based on their age (young adults). The inclusion criteria were: age 19-26 years, enrollment in a full-time bachelor's or master's degree program, and consent to participate in the study. A total of 132 respondents completed the questionnaire.

The respondents were surveyed remotely with the use of the Microsoft Forms online tool due to social distancing requirements. The study was conducted between 6 and 21 April 2010 when strict self-isolation and social distancing rules were in place (national quarantine).

Results A total of 132 university students, including $23 \%$ male and $77 \%$ female respondents, participated in the study. In the surveyed group, $73 \%$ of the respondents were enrolled in bachelor's (first-level) degree programs, and $27 \%$ of the subjects were enrolled in master's (second-level) degree programs.

The vast majority (97\%) of the respondents were aware that COVID-19 is caused by the SARS-CoV2 virus. Four of the surveyed subjects were not familiar with the term "SARSCoV2", which is highly surprising due to the extensive media coverage of the topic in recent months. There are two possible explanations for this:

- The respondents misinterpreted the question by assuming that in-depth knowledge about the virus was required (the survey was conducted at the beginning of the first wave of the epidemic).

- The respondents marked the wrong answer by mistake.

However, the remaining answers were rational; therefore, these questionnaires were considered in the analysis of the results.

Most of the surveyed subjects described their psychological well-being as very good and good before the outbreak of the epidemic, but a clear decline in mood was noted after the state of epidemic emergency had been declared (Fig. 1). Only one respondent claimed that his/her mood was poor before the epidemic, and none of the surveyed subjects described their mood as very bad before the lockdown. Most of the respondents evaluated their psychological well-being as fair during the lockdown, but 19 subjects described their mood as poor or very bad, which is a cause for concern. On the adopted scale, psychological well-being decreased by one level in 56 cases, by two levels in 30 cases, and by three and more levels in 8 cases.

The percentage changes in the respondents' psychological well-being are presented in Table 1. The number of subjects reporting very good and good mood decreased significantly during lockdown, and the highest change was noted in the number of respondents who described their mood as fair. Students described their mood as poor and very poor only during the lockdown. These results point to a clear deterioration in the respondents' psychological well-being.

The vast majority of the surveyed subjects (98\%) complied with lockdown rules (travel and movement of persons, outdoor activities, number of people moving and meeting in public spaces, reasonable excuse for leaving the house). According to the respondents, restricted access to public spaces was a major contributor to the decline in mood and quality of life. Social distancing rules significantly influenced the respondents' daily activities in public spaces (Fig. 2), social life (human interactions) and physical activities (mainly sports).

According to most respondents (72\%), the epidemic emergency exerted a negative or rather negative impact on their daily activities in public spaces (Fig. 3). Interestingly, $21 \%$ of the surveyed subjects claimed that lockdown rules had not affected their daily activities (neutral impact), and 2\% of the respondents declared that the state of emergency had a rather positive influence on their daily lives, whereas $5 \%$ were undecided.

The introduced restrictions influenced the frequency of visits and the scope of activities in both open and closed public spaces. Most respondents stayed in their place of residence during the pandemic, and in their opinion, lockdown rules had significantly affected their psychological and physical well-being. The decrease in the frequency of visits to public spaces during the state of epidemic emergency is presented in Figs. 4 and 5.

The percentage changes in the frequency of visits to public spaces before and during the lockdown are presented in Table 2. The frequency of visits to both closed and open public spaces decreased visibly during the epidemic, which had adverse effects on the respondents' social life and their psychological well-being. Social distancing also led to a decline in the students' physical activity which is essential for the maintenance of good health and a positive outlook on life. 
Fig. 1 The respondents' psychological well-being before and after the introduction of the state of emergency over the COVID-19 epidemic

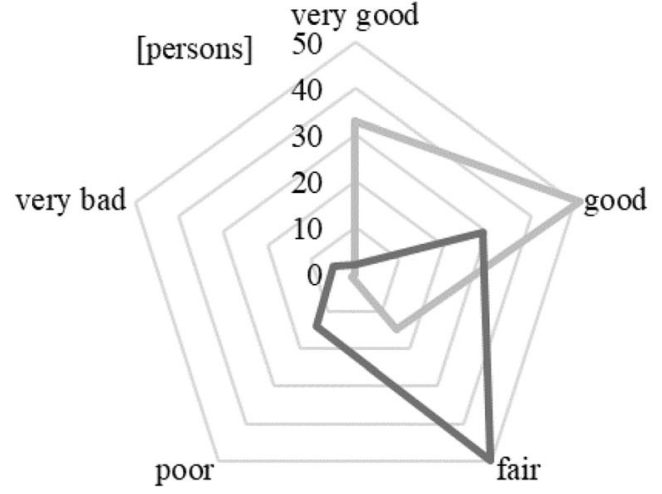

before lockdown

$\longrightarrow$ after lockdown
Despite the above, the surveyed students did not completely refrain from visiting public places, and $80 \%$ of the respondents had visited public spaces during the lockdown. The subjects left their home/place of residence for the following reasons: shopping for essential items such as food, medication, personal hygiene products (116 responses), walking the $\operatorname{dog}$ (32 responses), shopping for other items such as household goods, sweets and alcohol (27 responses), physical activity (27 responses), walk in the park/forest (22 responses), meeting family and friends (16 responses), helping neighbors (12 responses), and religious ceremonies (1 response). The respondents could declare more than one reason for leaving their homes during the lockdown.

The decline in the frequency of visits to public spaces exerted a negative impact on the surveyed students mainly due to the absence of human interactions. This opinion was voiced by $90 \%$ of the respondents. The students were most negatively affected by the lack of personal contact with friends (54\%) and family (38\%).

In the surveyed population, $51 \%$ of the respondents admitted that personal interactions in public spaces could be partially replaced by remote contact (Internet, telephone). Seven percent of the surveyed students were undecided, whereas the remaining $42 \%$ of the respondents were of the opinion that modern technology could not completely or partially replace direct human contact.

According to $68 \%$ of the subjects, the activities that are normally performed outdoors can be conducted indoors with

Table 1 Percentage decline in mood after the introduction of the state of emergency over the COVID-19 epidemic

\begin{tabular}{lll}
\hline Psychological well-being & Change & Description \\
\hline Very good & $-31 \%$ & Decline - undesirable outcome \\
Good & $-22 \%$ & Decline - undesirable outcome \\
Fair & $+35 \%$ & Increase - undesirable outcome \\
Poor & $+13 \%$ & Increase - alarming outcome \\
Very bad & $+5 \%$ & Increase-alarming outcome \\
\hline
\end{tabular}

the use of modern technology. These include exercise and online shopping. Eight percent of the respondents were undecided, whereas the remaining subjects were of the opposite opinion.

The reported decrease in the frequency of visits to public spaces also contributed to a significant decline in the level of activities that are normally performed in both closed and open public spaces. The results are presented in Figs. 6 and 7. Physical activity levels were indicated on a five-point scale to express a person's daily physical activity as a number. Only a descriptive scale (which is typically used in research) was presented in the questionnaire, and the respondents specified their level of agreement with a given statement in five points (Human energy requirements. Report of a Joint FAO/WHO/ UNU Expert Consultation 2001; Johansson and Westerterp 2008; Shetty et al. 1994):

- Activity level 1: basic, very low level of physical activity without indoor exercise or outdoor activity

- Activity level 2: low level of physical activity, several bouts of exercise per month, sporadic walks

- Activity level 3: moderate level of physical activity, several bouts of exercise per week (irregular) and outdoor activity (irregular)

- Activity level 4: high level of physical activity - regular exercise (3-5 times a week), regular outdoor activity

- Activity level 5: performance training

The percentage changes in activity levels in public spaces after the introduction of lockdown measures are presented in Table 3. A similar decrease in activity levels was noted in both closed and open public spaces. Lockdown rules significantly increased the number of respondents reporting very low levels of activity (level 1 and 2). These results are alarming, and they indicate that the surveyed respondents did not perform any indoor or outdoor exercise (walking, running, etc.) during the lockdown. Very low levels of physical activity have highly adverse consequences for the respondents' physical and mental health. 
Fig. 2 Has the epidemic affected your daily activities in public spaces?

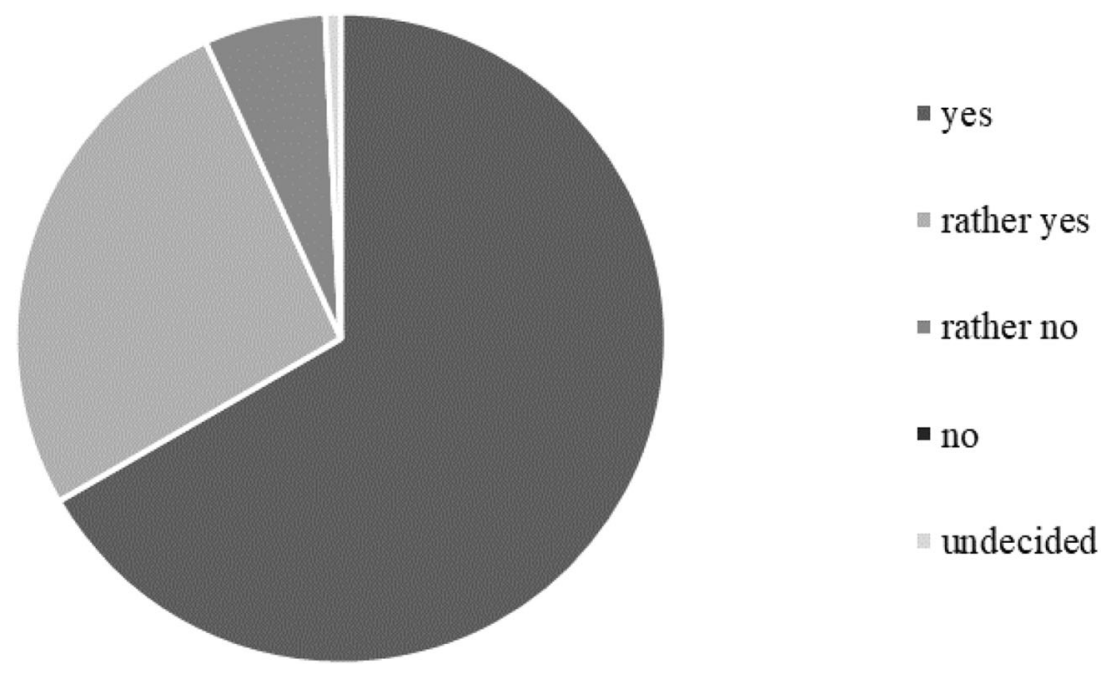

A list of public spaces whose closure caused the greatest inconvenience for the surveyed students is presented in Fig. 8 (the respondents could select more than once answer). The respondents were most negatively affected by the closure of bars, clubs, shopping centers, cinemas and museums - places that are frequently visited by young people. The students' well-being was also compromised by the lack of access to open public spaces such as forests, parks, streets, pavements, pedestrian zones, as well as sports fields, gyms and swimming pools which are essential for maintaining healthy levels of physical activity. The respondents were least inconvenienced by the closure of churches, markets and railway stations.

Lockdown rules restricting access to public spaces and the resulting decrease in the frequency of visits to public spaces and relevant activities negatively affected $91 \%$ of the surveyed students. These restrictions increased the respondents' appreciation of unlimited daily access to public spaces. The significance of public spaces was recognized by $89 \%$ of the subjects. Five respondents were undecided, whereas 10 students were of the opinion that public spaces do not exert an important or somewhat important influence on their physical and psychological well-being.

\section{Discussion and conclusions}

The COVID-19 epidemic has significantly affected people's daily lives and had far-reaching consequences (healthcare, economic, social) for people from different age groups (Gassman-Pines et al. 2020; Haleem et al. 2020; Patrick et al. 2020; Rodríguez-Rey et al. 2020; Qiu et al. 2020; Tull et al. 2020). This study attempted to survey the opinions of young adults who are university students. The respondents were asked to complete a questionnaire, and the results were processed to determine the influence of lockdown measures and restricted access to public spaces on the students' quality of life.
Fig. 3 The impact of the epidemic on daily activities in public spaces

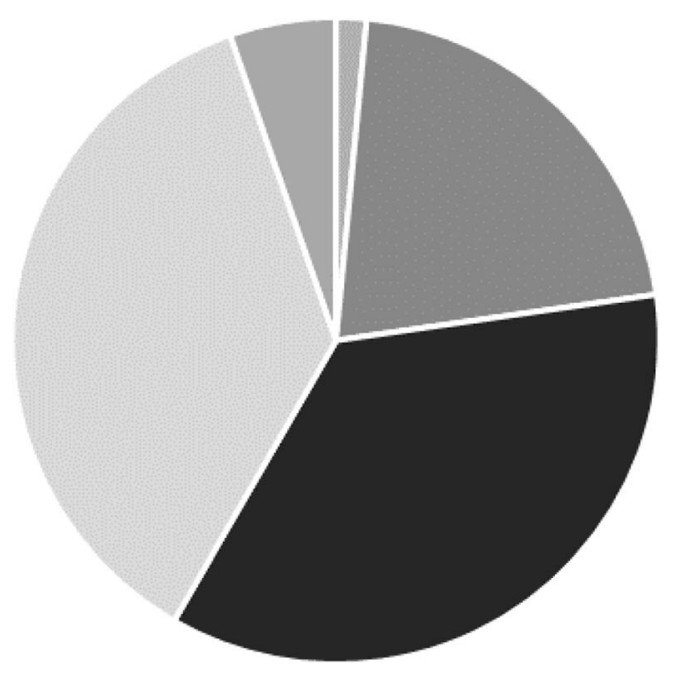

- positive

rather positive

- neutral

- rather negative

negative

" undecided 
Fig. 4 Frequency of visits to closed public spaces before and during the epidemic
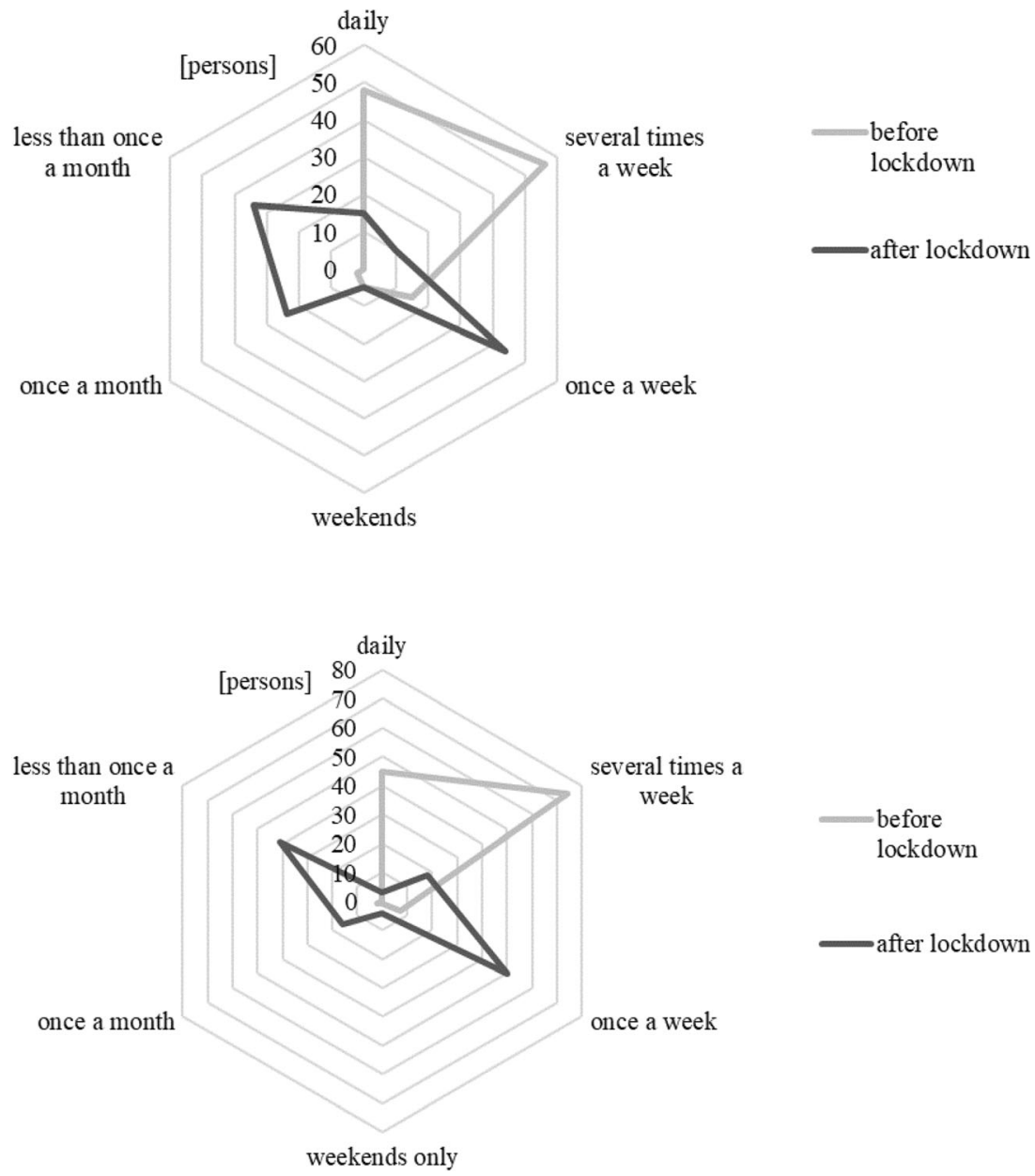

Fig. 5 Frequency of visits to open public spaces before and during the epidemic
The majority of the surveyed students complied with lockdown rules regarding social distancing. The introduced measures significantly limited access to both open and closed public spaces, and restricted outdoor activities to those that were deemed essential for satisfying basic survival needs. Young people were negatively affected by the introduced changes and restrictions in access to public spaces. The absence of daily contacts with friends during visits to bars, gyms, parks and swimming pools was a distressing experience which had a negative impact on the respondents' social lives and social interactions. These limitations were partially compensated for by modern technologies and remote communication tools such as the Internet and mobile phones. However, these means of communication cannot fully compensate for the loss of direct social contact in public spaces. Despite the fact that the surveyed students belong to the digital generation and have been familiar with modern technology and virtual communication tools since childhood, the majority of the

Table 2 Percentage changes in the frequency of visits to closed and open public spaces before and after the introduction of the state of emergency over the COVID-19 epidemic

\begin{tabular}{|c|c|c|c|c|}
\hline \multirow[t]{2}{*}{ Visit frequency } & \multicolumn{2}{|c|}{ Closed public spaces } & \multicolumn{2}{|c|}{ Open public spaces } \\
\hline & Change & Description & Change & Description \\
\hline Daily & $-25 \%$ & Decline - undesirable outcome & $-32 \%$ & Decline - undesirable outcome \\
\hline Several times a week & $-35 \%$ & Decline - undesirable outcome & $-42 \%$ & Decline - undesirable outcome \\
\hline Once a week & $+22 \%$ & Increase - undesirable outcome & $+33 \%$ & Increase - alarming outcome \\
\hline Weekends only & $0 \%$ & No change & $+2 \%$ & Increase - undesirable outcome \\
\hline Once a month & $+17 \%$ & Increase - alarming outcome & $+11 \%$ & Increase - alarming outcome \\
\hline Less frequently & $+21 \%$ & Increase - alarming outcome & $+29 \%$ & Increase - alarming outcome \\
\hline
\end{tabular}


Fig. 6 Activity levels in closed public spaces before and after lockdown $(1=$ low level of activity; $>5=$ high level of activity)
Fig. 7 Activity levels in open public spaces before and during the epidemic $(1=$ low level of activity; $>5=$ high level of activity)
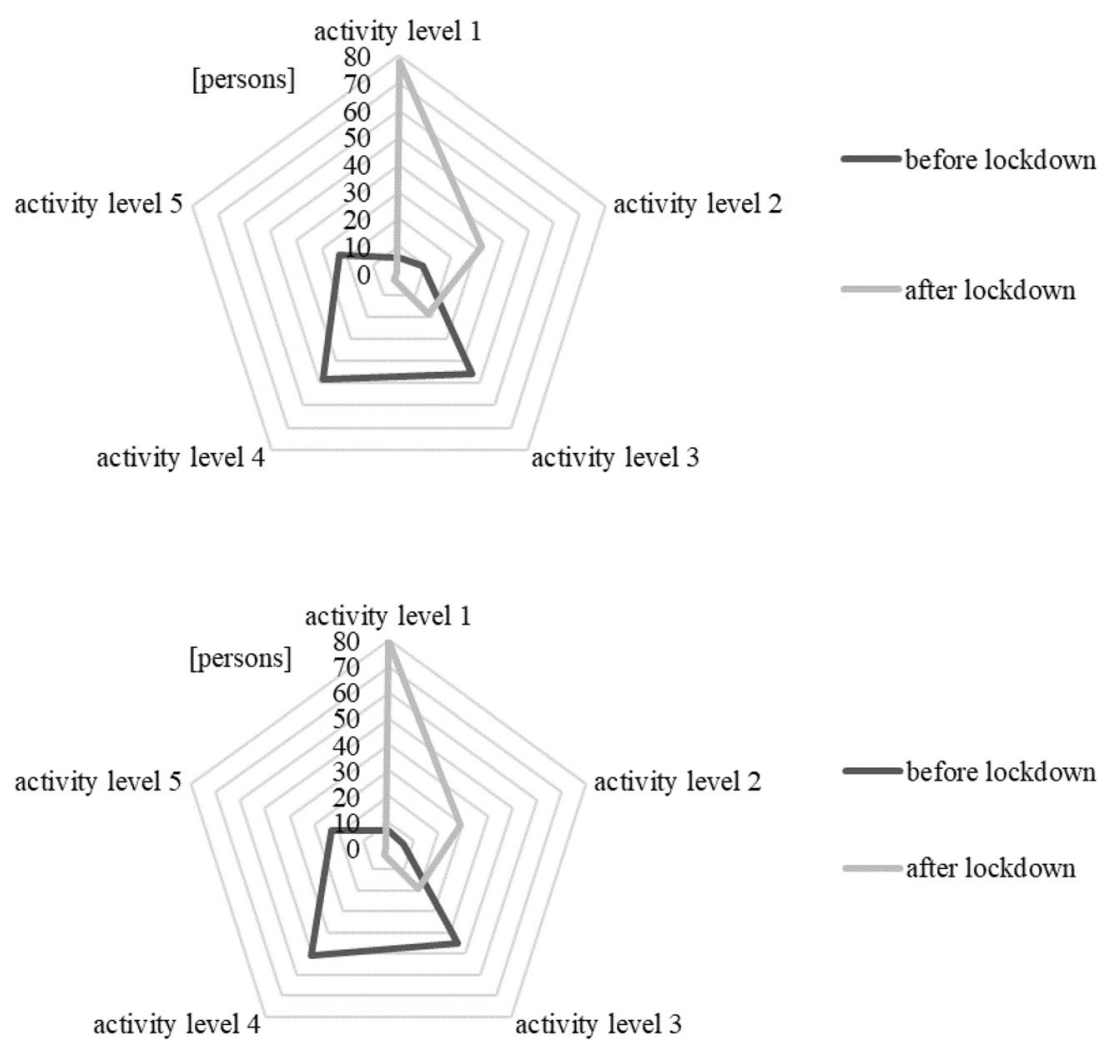

respondents were negatively affected by lockdown measures. The results of the questionnaire survey revealed that social distancing rules have increased the students' appreciation of direct human contact, in particular contact with friends.

The study demonstrated that the restrictions enforced during the COVID-19 pandemic contributed to a significant decline in the mood, psychological well-being and quality of life of young adults. Similar results were reported by researchers in other countries (Beam and Kim 2020; Liu et al. 2020a; Liu et al. 2020b; Parola et al. 2020; Shanahan et al. 2020; Volk et al. 2020; Zheng et al. 2020). Limited access to public spaces was strongly correlated with a decline in the students' psychological well-being. According to the respondents, the significant decrease in the frequency of visits to open and closed public spaces, and the resulting decline in physical and social activities (human interactions) had a highly negative impact on their psychological well-being and mood. The above also applies to respondents who had not experienced psychological discomfort before the lockdown. The surveyed students nearly unanimously claimed that the quality of their lives had deteriorated due to social distancing.

The study had several limitations. It was conducted on members of a selected social group with high computer and Internet skills. The survey took place during the first national lockdown when the respondents found themselves in a completely new reality. Therefore, the current findings could not be compared with the results of previous surveys that were conducted in a similar social situation.

Further consequences of the COVID-19 pandemic lockdown will be explored in a follow-up survey that will be conducted in the same social group after several months.
Table 3 Percentage changes in activity levels in closed and open public spaces before and after the introduction of the state of emergency over the COVID-19 epidemic

\begin{tabular}{|c|c|c|c|c|}
\hline \multirow[t]{2}{*}{ Activity level } & \multicolumn{2}{|c|}{ Closed public spaces } & \multicolumn{2}{|c|}{ Open public spaces } \\
\hline & Change & Description & Change & Description \\
\hline Activity level 1 & $+55 \%$ & Increase - alarming outcome & $+55 \%$ & Increase - alarming outcome \\
\hline Activity level 2 & $+17 \%$ & Increase - alarming outcome & $+17 \%$ & Increase - alarming outcome \\
\hline Activity level 3 & $-21 \%$ & Decline - undesirable outcome & $-20 \%$ & Decline - undesirable outcome \\
\hline Activity level 4 & $-34 \%$ & Decline - undesirable outcome & $-36 \%$ & Decline - undesirable outcome \\
\hline Activity level 5 & $-17 \%$ & Decline - undesirable outcome & $-17 \%$ & Decline - undesirable outcome \\
\hline
\end{tabular}


Fig. 8 Public spaces whose closure caused the greatest inconvenience

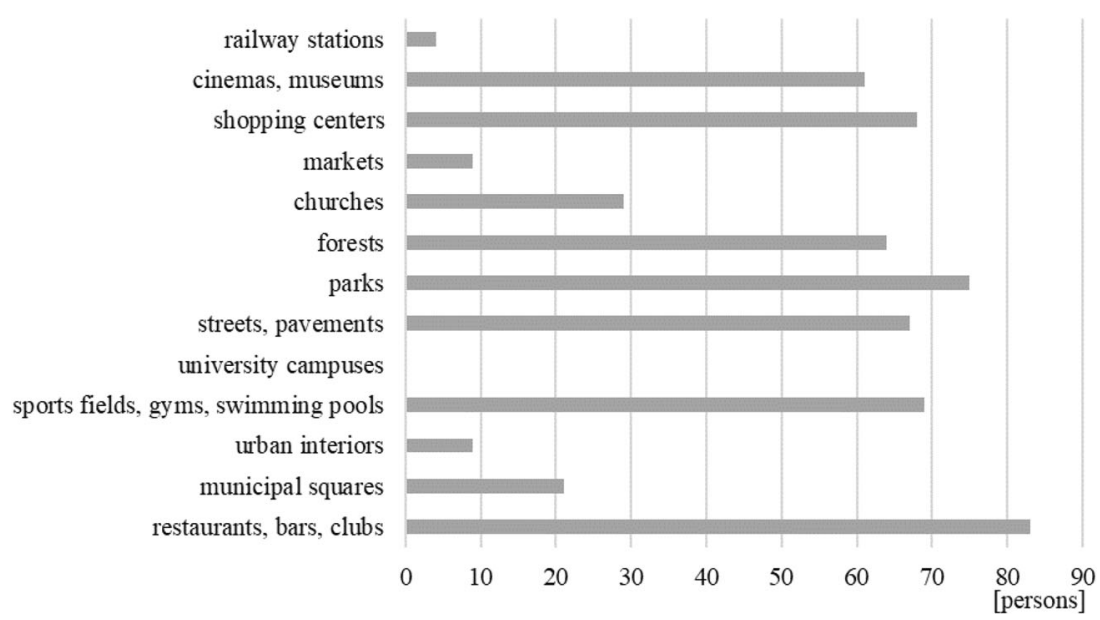

Authorship contribution statement Conceptualization: A.Sz. and K.P.; methodology: A.Sz. and K.P.; formal analysis: A.Sz. and K.P.; investigation: A.Sz. and K.P., data curation: K.P.; writing - original draft preparation: A.Sz. and K.P.; visualization: A.Sz.; supervision: A.Sz.

Role of funding source This research received no grant from any funding agency in the public, commercial or not-for-profit sectors.

\section{Compliance with ethical standards}

All the procedures contributing to this work comply with the ethical standards.

Informed consent Participation in the study was anonymous and voluntary.

Conflict of interest The authors declare that they have no conflict of interest.

\section{References}

Adamiak G, Świątnicka E, Wołodźko-Makarska L, Świtalska MJ (2004) Ocena jakości życia studentów medycyny w zależności od liczby i nasilenia stwierdzonych objawów depresyjnych. Psychiatr Pol 38: 631-638

Amin A (2008) Collective culture and urban public space. https://doi.org/ $10.1080 / 13604810801933495$

Anderson KJ (2001) Internet use among college students: an exploratory study. J Am Coll Heal. https://doi.org/10.1080/ 07448480109595707

Armitage R, Nellums LB (2020) COVID-19 and the consequences of isolating the elderly. Lancet Public Health. https://doi.org/10.1016/ S2468-2667(20)30061-X

Aydin D, Ter U (2008) Outdoor space quality: case study of a univeristy campus plaza. Archnet-IJAR Int J Architect Res 2(3):189-120

Banjanin N, Banjanin N, Dimitrijevic I, Pantic I (2015) Relationship between internet use and depression: focus on physiological mood oscillations, social networking and online addictive behavior. Comput Hum Behav. https://doi.org/10.1016/j.chb.2014.11.013

Beam CR, Kim AJ (2020) Psychological sequelae of social isolation and loneliness might be a larger problem in young adults than older adults. Psychol Trauma Theory Res Pract Policy 12(S1):5860.https://doi.org/10.1037/tra0000774
Białkowska J, Mroczkowska D, Zomkowska E, Rakowska A (2014) Ocena zdrowia psychicznego studentów na podstawie Skróconego Kwestionariusza Zdrowia Pacjenta. Hygeia Public Health 49(2): 365-369

Biddle SJ, Fox K, Boutcher S (eds) (2003) Physical activity and psychological well-being. Routledge

Bray SR, Born HA (2004) Transition to university and vigorous physical activity: implications for health and psychological well-being. Journal of American College Health 52(4):181-188.https://doi. org/10.3200/JACH.52.4.181-188

Braubach M, Egorov A, Mudu P, Wolf T, Thompson C W, Martuzzi M (2017) Effects of urban green space on environmental health, equity and resilience in: Kabisch N, Korn H, Stadler J, Bonn a (ed.), naturebased solutions to climate change adaptation in urban areas, linkages between science, policy and practice, springer open, pp. 187-205

Brooks F, Magnusson J (2007) Physical activity as leisure: the meaning of physical activity for the health and well-being of adolescent women. Health Care Women Int. https://doi.org/10.1080/ 07399330601003499

Cain J (2008) Online social networking issues within academia and pharmacy education. Am J Pharm Educ. https://doi.org/10.5688/aj720110

Caldwell K, Harrison M, Adams M, Triplett NT (2009) Effect of Pilates and taiji quan training on self-efficacy, sleep quality, mood, and physical performance of college students. J Bodyw Mov Ther. https://doi.org/10.1016/j.jbmt.2007.12.001

Canet-Juric L, Andrés LM, del Valle M, López-Morales H, Poó F, Galli IJ, Yerro M, Urquijo S (2020) A longitudinal study on the emotional impact cause by the COVID-19 pandemic quarantine on general population. Front Psychol 11:1-17

Cao W, Fang Z, Hou G, Han M, Xu X, Dong J, Zheng J (2020) The psychological impact of the COVID-19 epidemic on college students in China. Psychiatry Res. https://doi.org/10.1016/j.psychres. 2020.112934

Caplan SE (2003) Preference for online social interaction: a theory of problematic internet use and psychosocial well-being. Commun Res. https://doi.org/10.1177/0093650203257842

Carr S, Stephen C, Francis M, Rivlin LG, Stone AM (1992) Public space. Cambridge University Press

Chen YF, Peng SS (2008) University students' internet use and its relationships with academic performance, interpersonal relationships, psychosocial adjustment, and self-evaluation. CyberPsychol Behav. https://doi.org/10.1089/cpb.2007.0128

Cieślik, Ostrowska B, Szczepańska-Gieracha J, Radziszewski Ł (2015) Aktywność zawodowa a zaburzenia nastroju wśród absolwentów fizjoterapii Akademii Wychowania Fizycznego we Wrocławiu. Rozprawy Naukowe Akademii Wychowania Fizycznego we Wrocławiu 48:113-118 
Ćosić K, Popović S, Sarlija M, Kesedzić I (2020) Impact of human disasters and Covid-19 pandemic on mental health: potential of digital psychiatry. Psychiatr Danub 32(1):25-31. https://doi.org/10. 24869/psyd.2020.25

Crane PR (2000) Young people and public space: developing inclusive policy and practice. Scottish Youth Issues J 1:105-124

Çuhadar C (2012) Exploration of problematic internet use and social interaction anxiety among Turkish pre-service teachers. Comput Educ. https://doi.org/10.1016/j.compedu.2011.12.029

Degórska B (2004) Planowanie terenów otwartych w nowej przestrzeni miejskiej (na przykładzie strefy podmiejskiej Warszawy) In: Kistowski M (ed.), Studia ekologiczno-krajobrazowe w programowaniu rozwoju zrównoważonego. Przegląd polskich doświadczeń u progu integracji z Unią Europejską. Dom Wydawniczy ABC, Gdańsk, pp 141-148

Derek M (2014) Miejska przestrzeń czasu wolnego. In: Madurowicz M (ed) Kształtowanie współczesnej przestrzeni miejskiej. Wyd. Uniwersytetu Warszawskiego, Warszawa, pp 210-217

Długosz P (2020) Raport z badań: „Krakowscy studenci w sytuacji zagrożenia pandemią koronawirusa. Instytut Filozofii i Socjologii Uniwersytetu Pedagogicznego im. Komisji Edukacji Narodowej w Krakowie, Kraków

Duszyński J, Afelt A, Ochab-Marcinek A, Owczuk R, Pyrć K, Rosińska M, Rychard A, Smiatacz T (2020) Zrozumieć COVID-19, Opracowanie Zespołu ds. Covid-19 przy Prezesie Polskiej Akademii Nauk. Polska Akademia Nauk, Warszawa, pp 28-30

Eckersley RM, Wierenga A, Wyn J (2005) Life in a time of uncertainty: Optimising the health and wellbeing of young Australians. Med J Aust. https://doi.org/10.5694/j.1326-5377.2005.tb07102.x

Fiorillo A, Gorwood P (2020) The consequences of the COVID-19 pandemic on mental health and implications for clinical practice. European Psychiat. https://doi.org/10.1192/j.eurpsy.2020.35

Francis J, Giles-Corti B, Wood L, Knuiman M (2012) Creating sense of community. Role Publ Space: J Environ Psychol 32(4):401-409. https://doi.org/10.1016/j.jenvp.2012.07.002

Gassman-Pines A, Ananat EO, Fitz-Henley J (2020) COVID-19 and parent-child psychological well-being. Pediatrics 146(4). https:// doi.org/10.1542/peds.2020-007294

Gruszczyński W, Zboralski K, Bielawski E (2008) Zespoły depresyjne w populacji studentów uczelni łódzkich. -Zdrowie. Psychiczne 3(1-2): 92-99

Haleem A, Javaid M, Vaishya R (2020) Effects of COVID 19 pandemic in daily life. Current Med Res Pract 10(2):78-79. https://doi.org/10. 1016/j.cmrp.2020.03.011

Hampton KN, Livio O, Sessions Goulet L (2010) The social life of wireless urban spaces: internet use, social networks, and the public realm. J Commun. https://doi.org/10.1111/j.1460-2466.2010. 01510.x

Hampton KN, Goulet LS, Albanesius G (2015) Change in the social life of urban public spaces: the rise of mobile phones and women, and the decline of aloneness over 30 years. Urban Stud. https://doi.org/ $10.1177 / 0042098014534905$

Hanan H (2013) Open space as meaningful place for students in ITB campus. Procedia Soc Behav Sci. https://doi.org/10.1016/j.sbspro. 2013.08.361

Heitzman J (2020) Impact of COVID-19 pandemic on mental health. Psychiatr Pol 54(2):187-198. https://doi.org/10.12740/PP/120373

Ho CS, Chee CY, Ho RC (2020) Mental health strategies to combat the psychological impact of COVID-19 beyond paranoia and panic. Ann Acad Med Singap 49(1):1-3

Honey-Rosés J, Anguelovski I, Bohigas J, Chireh V, Daher C, Konijnendijk C, Litt J, Mawani V, McCall M, Orellana A, Oscilowicz E, Sánchez U, Senbel M, Tan X, Villagomez E, Zapata O, Nieuwenhuijsen M (2020) The impact of COVID-19 on public space: a review of the emerging questions - design, perceptions and inequities. Cities Health. https://doi.org/10.1080/ 23748834.2020.1780074

Human energy requirements. Report of a Joint FAO/WHO/UNU Expert Consultation (2001) FAO food and nutrition technical report series. Rome, Italy

Huynh Q, Craig W, Janssen I, Pickett W (2013) Exposure to public natural space as a protective factor for emotional well-being among young people in Canada. BMC Public Health. https://doi.org/10. 1186/1471-2458-13-407

Jasiński A (2020) Public space or safe space - remarks during the COVID-19 pandemic. Tech Trans 20:1-10. https://doi.org/10. 37705/TechTrans/e2020020

Jaworska L, Morawska N, Morga P, Szczepańska-Gieracha J (2014) Analiza częstości występowania objawów depresyjnych wśród studentów Wydziału Fizjoterapii Akademii Wychowania Fizycznego we Wrocławiu w kontekście planów zawodowych. Fizjoterapia 22(3):10-22

Johansson G, Westerterp KR (2008) Assessment of the physical activity level with two questions: validation with doubly labeled water. Int J Obes 32(6):1031-1033. https://doi.org/10.1038/ijo.2008.42

Jones S (2008) Internet goes to college: how students are living in the future with today's technology. Diane Publishing

Király O, Potenza MN, Stein DJ, King DL, Hodgins DC, Saunders JB, Gjoneska B, Billieux J, Brand M, Abbott MW, Chamberlain SR, Corazza O, Burkauskas J, Sales CMD, Montag C, Lochner C, Grünblatt E, Demetrovics Z (2020) Preventing problematic internet use during the COVID-19 pandemic: consensus guidance. Compr Psychiatry 100:1-4. https://doi.org/10.1016/j.comppsych.2020. 152180

Koszel M, Kocira S, Lorencowicz E (2015) Zmiany w technikach komunikacji internetowej studentów. Edukacja-TechnikaInformatyka 4(14):118-124

Krajewska-Kułak E, Kułak W, Van Damme-Ostapowicz K, Lewko J, Łukaszuk C, Bielemuk A, Kowalczuk K, Rolka H, Kowalewska B, Jankowiak B, Rozwadowska E (2010) Uzależnienie od Internetu wśród studentów kierunku pielęgniarstwo. Problemy Higieny i Epidemiologii 91(1):41-47

Łakomski M, Pietsch J, Chłystek J, Abramczyk A, Golus A, Zukow W (2017) Wpływ aktywności ruchowej na nastrój - przegląd aktualnego piśmiennictwa. J Education, Health Sport. https://doi. org/10.5281/zenodo.822432

Legey S, Aquino F, Lamego MK, Paes F, Nardi AE, Neto GM, Mura G, Sanscassiani F, Rocha N, Murillo-Rodriguez E, Machado S (2017) Relationship among physical activity level, mood and anxiety states and quality of life in physical education students. Clin Pract Epidemiol Ment Health. https://doi.org/10.2174/ 1745017901713010082

Lesser AI, Nienhuis PC (2020) The impact of COVID-19 on physical activity behavior and well-being of Canadians. Int J Environ Res Public Health 17(11). https://doi.org/10.3390/ijerph17113899

Li S (2010) The online public space and popular ethos in China. Media Culture Soc. https://doi.org/10.1177/0163443709350098

Li S, Wang Y, Xue J, Zhao N, Zhu T (2020) The impact of COVID-19 epidemic declaration on psychological consequences: a study on active Weibo users. Int J Environ Res Public Health. https://doi. org/10.3390/ijerph17062032

Lima CKT, de Medeiros Carvalho PM, Lima IDAS, de Oliveira Nunes JVA, Saraiva JS, de Souza RI, Lima da Silva CG, Neto MLR (2020) The emotional impact of coronavirus 2019-nCoV (new coronavirus disease). Psychiatry Res. https://doi.org/10.1016/j.psychres.2020. 112915

Lis R (2010) Problem nadmiernego zaangażowania studentów w aktywności internetowej. Postępy Nauki i Techniki 4:12-22

Liu CH, Stevens C, Conrad RC, Hahm HC (2020a) Evidence for elevated psychiatric distress, poor sleep, and quality of life concerns during the COVID-19 pandemic among US young adults with suspected 
and reported psychiatric diagnoses. Psychiatry research. 292. https:// doi.org/10.1016/j.psychres.2020.113345

Liu, CH, Stevens C, Conrad RC, Hahm, HC (2020b) Evidence for elevated psychiatric distress, poor sleep, and quality of life concerns during the COVID-19 pandemic among US young adults with suspected and reported psychiatric diagnoses. Psychiatry Research 292:113345. https://doi.org/10.1016/j.psychres.2020.113345

Lopes PN, Salovey P, Côté S, Beers M, Petty RE (2005) Emotion regulation abilities and the quality of social interaction. Emotion. https:// doi.org/10.1037/1528-3542.5.1.113

Marcinkowski JT, Bajek A, Galewska I (2010) Aktywność studentów w Internecie-oceniana pod kątem uzależnienia od Internetu. Hygeia Public Health 45(2):135-142

Marek K, Białoń P, Wichowicz H, Melloch H, Nitka-Siemińska A (2005) Przesiewowa ocena rozpowszechnienia objawów depresyjnych i lękowych wśród studentów Akademii Medycznej w Gdańsku. Psychiatria 2(4):217-224

Martínez-Alemán AM, Wartman KL (2008) Online social networking on campus: understanding what matters in student culture. Routledge

Mitchell D (1995) The end of public space? People's Park, definitions of the public, and democracy. Ann Assoc Am Geogr 85(1):108-133

Montemurro N (2020) The emotional impact of COVID-19: from medical staff to common people. Brain Behav Immun. https://doi.org/10. 1016/j.bbi.2020.03.032

Moturu T, Khayal I, Aharony N, Pan W, Pentland A (2011) Sleep, mood and sociability in a healthy population. In Proceedings of the Annual International Conference of the IEEE Engineering in Medicine and Biology Society 5267-5270.https://doi.org/10.1109/IEMBS.2011. 6091303

Nobajas A, Ganau i Casas J, Paül i Agustí D, Peacock A (2020) Lack of sufficient public space can limit the effectiveness of COVID19's social distancing measures. medRxiv https://doi.org/10.1101/2020. 06.07.20124982

Palinkas LA, Johnson JC, Boster JS (2004) Social support and depressed mood in isolated and confined environments. Acta Astronautica 54(9):639-647

Park N (2010) Integration of internet use with public spaces: college students' use of the wireless internet and offline socializing. Cyberpsychol J Psychosocial Res Cyberspace. https://doi.org/10. 1016/S0094-5765(03)00236-4

Parola A, Rossi A, Tessitore F, Troisi G, Mannarin, S (2020) Mental health through the COVID-19 quarantine: a growth curve analysis on Italian young adults. Frontiers in Psychology 11:567484. https:// doi.org/10.3389/fpsyg.2020.567484

Patrick SW, Henkhaus LE, Zickafoose JS, Lovell K, Halvorson A, Loch S, Letterie S, Davis MM (2020) Well-being of parents and children during the COVID-19 pandemic: a national survey. Pediatrics 146: 4. https://doi.org/10.1542/peds.2020-016824

Prakash S, Yadav JS, Singh TB (2020) An online cross-sectional study to assess the prevalence of internet addiction among people staying at their home during lockdown due to COVID-19. Int J Indian Psychol 8(3):424-432. https://doi.org/10.25215/0803.052

Qiu J, Shen B, Zhao M, Wang Z, Xie B, Xu Y (2020) A nationwide survey of psychological distress among Chinese people in the COVID-19 epidemic: implications and policy recommendations. General psychiatry 33(2). https://doi.org/10.1136/gpsych-2020100213

Regulation of the Minister of Health of 20 March (2020) Introducing a nationwide state of epidemic on the territory of the Republic of Poland. J Laws 2020 item 491

Regulation of the Minister of Health of 24 March 2020 amending the Regulation introducing a nationwide state of epidemic on the territory of the Republic of Poland. J Laws 2020 item 522

Rodríguez-Rey R, Garrido-Hernansaiz H, Collado S (2020) Psychological impact and associated factors during the initial stage of the coronavirus (COVID-19) pandemic among the general population in Spain. Front Psychol 11:1540. https://doi.org/10. 3389/fpsyg.2020.01540

Santi G, Leporelli E (2019) From psychology of sustainability to sustainability of urban spaces: promoting a primary prevention approach for well-being in the healthy City designing. A Waterfront Case Study Livorno Sustainability 11(3):706. https://doi.org/10.3390/ su11030760

Schwerdtfeger A, Friedrich-Mai P (2009) Social interaction moderates the relationship between depressive mood and heart rate variability: evidence from an ambulatory monitoring study. Health Psychol. https://doi.org/10.1037/a0014664

Shaftoe H (2012) Convivial urban spaces: creating effective public places. Earthscan, London

Shanahan L, Steinhoff A, Bechtiger L, Murray AL, Nivette A, Hepp U, Ribeaud D, Eisner M (2020) Emotional distress in young adults during the COVID-19 pandemic: evidence of risk and resilience from a longitudinal cohort study. Psychol Med 2020:1-10. https:// doi.org/10.1017/S003329172000241X

Shetty PS, Henry CJK, Black AE, Prentice AM (1994) Total energy expenditure (TEE) and physical activity levels (PAL) in adults: doubly-labelled water data in: energy and protein requirements, proceedings of an IDECG workshop. Supplement of the European Journal of Clinical Nutrition, IDECG, London

Sikorska P (2010) Przestrzeń otwarta miasta pod presją rozwoju :przyczyny zjawiska i kierunki działań naprawczych : przypadek Mazowsza. MAZOWSZE Studia Regionalne 5:155-182

Swist T, Collin P, McCormack J, Third A (2015) Social media and the wellbeing of children and young people: a literature review. Commissioner for Children and Young People, Western Australia

Szczepańska J, Klin Z, Jaroszewska A, Ciesielski R (2008) Zaburzenia nastroju w populacji studentów Wydziału Fizjoterapii AWF we Wrocławiu. Część 1. Physiotherapy/Fizjoterapia 16(3):69-78

Taras H (2005) Physical activity and student performance at school. J Sch Health. https://doi.org/10.1111/j.1746-1561.2005.tb06675.x

Tonnelat S (2010) The Sociology of Urban Public Spaces. In: Hongyang W, Michel S, Guofang Z (eds.), Territorial Evolution and Planning Solution: Experiences from China and France, Paris: Atlantis Press, pp. 84-92.

Torales J, O'Higgins M, Castaldelli-Maia JM, Ventriglio A (2020) The outbreak of COVID-19 coronavirus and its impact on global mental health. Int J Soc Psychiatry. https://doi.org/10.1177/ 0020764020915212

Tull M T, Edmonds K A, Scamaldo K, Richmond J R, Rose J P, Gratz K L (2020) Psychological Outcomes Associated with Stay-at-Home Orders and the Perceived Impact of COVID-19 on Daily Life. Psychiatry Resarch 289:113098. https://doi.org/10.1016/j.psychres. 2020.113098

Uramowska-Zyto B, Kozlowska-Wojciechowska M, Jarosz A, Makarewicz-Wujec M (2004) Wybrane elementy stylu życia studentów wyśszych uczelni w świetle badan empirycznych. Roczniki Państwowego Zakładu Higieny 2(55):171-179

Volk A A, Brazil K J, Franklin-Luther P, Dane A V, Vaillancourt T (2020) The influence of demographics and personality on COVID19 coping in young adults. Personality and Individual Differences 168:110398. https://doi.org/10.1016/j.paid.2020.110398

Wang C, Pan R, Wan X, Tan Y, Xu L, Ho CS, Ho RC (2020) Immediate psychological responses and associated factors during the initial stage of the 2019 coronavirus disease (COVID-19) epidemic among the general population in China. Int J Environ Res Public Health. https://doi.org/10.3390/ijerph17051729

Wilczewska A (2013) Samoocena i poziom depresji studentów kierunków pedagogicznych i niepedagogicznych. Rozprawy Społeczne 7(1):109-124

Wood L, Hooper P, Foster S, Bull F (2017) Public green spaces and positive mental health-investigating the relationship between 
access, quantity and types of parks and mental wellbeing. Health Place. https://doi.org/10.1016/j.healthplace.2017.09.002

Wyn J, Cuervo H, Woodman D, Stokes H (2005) Young people, wellbeing and communication technologies. VicHealth, Melbourne

Zheng C, Huang WY, Sheridan S, Sit CHP, Chen XK, Wong SHS (2020)

COVID-19 pandemic brings a sedentary lifestyle in young adults: a cross-sectional and longitudinal study. Int J Environ Res Public Health 17(17). https://doi.org/10.3390/ijerph17176035

Publisher's note Springer Nature remains neutral with regard to jurisdictional claims in published maps and institutional affiliations. 